\title{
The Impact of Education on Economic Growth in Jordan during (1960-2016)
}

\author{
MALIK QASIM KHASAWNEH \\ Associate Prof, Taibah University, Economic and Finance Division, Kingdom of Saudi Arabia \\ Email: malik.khasawneh@yahoo.com
}

\begin{abstract}
This study examines the relationship between economic growth and education in Jordan using the vector error correction model (VECM) and other necessary tests during the period 1960-2016. The variables that data used are GDP per capita, gross enrollment rate, government expenditures on education, literacy rate, life expectation, fertility rate, inflation, and openness ratio. Our findings indicate that There is a negative relationship between economic growth and gross enrollment rate (GER), and there is a negative relationship between economic growth and fertility rate $(F R)$. On the other hand, the study finds that there is a positive relationship between economic growth and government expenditures on education (EDX), literacy rate (LR), life expectancy $(L E)$, inflation $(I N)$ and openness ratio $(O R)$.
\end{abstract}

Keywords: Education, Economic Growth, Government Expenditures on Education, Unit Root Tests, Cointegration, Vector Error Correction Model (VECM).

\section{Introduction}

Investing in education is vital to achieve sustainable economic growth over time and much of the growth in gross domestic product per capita and productivity are attributed through investing in worker's capacity and a better educated labor force. So, education is vital instrument for economic growth and development and this required to concentrate heavily in the quantity and the quality of education.

Regarding that, we can say that societies with high levels of education may have a high level of income than societies whom their educational level is poor or not developed. Even though investment in education at the individual level raises also their individual income, so it is possible to conclude that education contributes to economic growth through the development of individual productivity, and through developing technological knowledge.

Jordan is one of the countries that take under consideration the importance of education sector in developing high quality human capital which has been the key contributor to its historic economic growth. But unfortunately Jordan cannot continue in its development steps in education development to increase prosperity of human capital capacity because of population increases, fiscal tightening and pressures on Jordan's education infrastructure which has opened its doors for Syrian refugees. In this paper and because of these obstacles that faces the educational sector in Jordan, the researcher aims to investigate the relationship between economic growth and education in Jordan during the period (1960-2016).

The remainder of the paper is organized as follows. Section 2 we specify the literature review in education. section 3 describers the data and methodology used in the analysis. section 4 discuss the results of estimation and finally the references. 


\section{Literature Review}

Education is considered as one of the main instruments in reducing poverty, inequality and as an association to create economic growth. Blaug (1975), showed that A. Smith (1776) defined human capital as a principal institutional mechanism of production, accumulation and diffusion of human capital, by paying attention to education as a social product, the role and the importance of knowledge and human resources gains a crucial role in explaining the growth. Human capital stimulates economic growth through three channels. First, education facilitates the diffusion and transmission of knowledge which is necessary to understand and process new information and to implement new technologies successfully, also leading to economic growth (Nelson and Phelps, 1966). Second, education increases human capital inherent in labour force, which enhances labour productivity and thus transitional growth towards a higher equilibrium level of output (neoclassical growth theories, Mankiw, Romer and Weil, 1992). Third, education can increase the innovative power of an economy as well as knowledge on new technologies, products and processes that promote growth (endogenous growth theories. Lucas, 1988; Romer, 1990).

Barro (2013), aims to analyze the determinants of economic growth and investment during the period (1960-1995), and the results show that education and the level of average years of school attainment of adult males (secondary and high levels) are positively related to the growth rate of Gross Domestic Product (GDP). Growth is insignificantly related to years of school attainment of females and the secondary and high levels. The results suggest that high educated women are not well utilized in the labor market of many countries. Growth is insignificantly related to male schooling at the primary level and this would affect growth rate. Education of women at primary level stimulates economic growth indirectly by inducing lower fertility rate.

Gilead (2012), examines from a philosophical perspective, the link between education and the currently prevailing understanding of economic progress, which is grounded in human capital theory, and investigate the foundations of human capital theory conception of economic progress. He argued that there are inherent tensions between the philosophical foundations of the economist's conception of progress and the very essence of education, and in order to resolve these tensions we should consider grounding the economic theory that guides educational policy-making in an inter subjective or objective conception of welfare.

Schlottmann (2010) argues that Southern Nevada needs to develop cluster based economic development and diversification strategies taking under consideration policy priority for higher education investment depend on necessary conditions that are multi-dimensional to achieve success. Successful cluster development requires a critical foundation of higher education and the associated commitment by public policy. This includes economic development related to a health cluster and targeted clusters in information technology, life sciences, office and security. Cluster jobs related to higher education translate into higherpaying jobs, this will also provide a wide range of support jobs for the entire labor force encompassing all skill levels in Southern Nevada. Higher education, with its networks and linkages is uniquely positioned to bring together representatives from diverse business, community and governmental groups to create the collaborations needed to develop the industry clusters that ensure the long-term sustainability of the Southern Nevada and Nevada economies. Successful economic development efforts depend on high quality educational resources and workforce. In this respect, an investment in a strong and high quality higher education system is an investment in the long-term economic evolution and sustainability with significant payoffs in the future. So, the utilization of infrastructure and technology requires a leading role of higher education system in regional economic development.

Afzal et al (2010) investigated the impact of school education on economic growth in Pakistan during the period (1970-2009). The results confirm a direct relationship between school education and economic growth in the short and long-run. In addition, School education and economic growth are inversely related to each other only in the short run. 
Danacica, Belascu \& Llie (2010) explore the causal nexus between higher education and economic growth in Romania during the period (1980-2008). The results confirmed that there is a long run relationship between higher education and economic growth.

Hanushek and Wobmann (2007) examined the role of education in promoting economic growth by studying the role of education quality. The results indicate that differences in learning achievements matter more in explaining cross-country differences in productivity growth than differences in the average number of years of schooling or in enrollment rates. A development-effective educational strategy must focus not only on sending more children to school, but also on maintaining or enhancing the quality of schooling. Reducing disparities and the quality of, education are two goals that must be achieved for any education reform to be success. Countries should investigate what the precise causes are in their own context and should be encouraged to experiment in finding the best way to correct weaknesses. Effective teacher certification, public disclosure of the educational achievements of schools and teachers, local school control by parents, and, the ability of teachers and head teachers, can be useful starting points for reflection. Education reforms take time to mature and bear fruit. Engaging in such reflection and experimentation is therefore urgent for development.

Bartik and Erickcek (2007), examine the effects of expansion in higher educational institutions and the medical service industry on the economic development of a metropolitan area in Philadelphia state in U.S.A. The study provides quantitative evidence of the magnitude of economic effects of higher education and medical service industries that occur through the mechanism of providing some export-base demand stimulus to a metropolitan economy. Also, the study provides quantitative evidence on how much higher education institutions can boost a metropolitan economy through increasing the educational attainment of local residence. The results show that medical service industries pay above average wages, holding worker characteristics constant, whereas the higher education industry pays below average wages; the wage standards of these industries may affect overall metropolitan wages. In addition, the study concludes that medical service industry and education industry may boost a metropolitan economy by increasing local amenities, generating research and development $(R \& D)$ spillovers, increasing the rate of entrepreneurship in local businesses, and helping provide local leadership on development and growth issues.

Dickens et al (2006), believe that human capital is essential and it needs more investment in the future especially in education and the reason is because economy is turning back to what is known knowledge based economy. Investment in education leads to restructuring the and developing human capital as well as physical and social capital.

Carpentier (2006), reveals that during $19^{\text {th }}$ and $20^{\text {th }}$ centuries enrollment in public education grown by 40 percent, while public expenditures on education also increased from 0.86 percent to 4.85 of Gross Domestic Product (GDP), taking under consideration that GDP also has been increased nine times.

Lin (2006) tests the hypothesis that the impact of education on growth per unit of education differs at different levels of schooling in Taiwan during the period (1964-2000). The analysis shows that elementary education has played a remarkable role in Taiwan's economic development in the past four decades. Thus, these findings suggest that educators and policy makers value the importance of a strong education foundation (i.e., elementary education). The study also suggests that the government not only needs to enhance the quality of higher education training, but also needs to improve the quality of primary and secondary education training.

Echevarria and Iza (2006), analyze the effects of changes in the mortality rate upon life expectancy, education, retirement age, human capital and growth in the presence of social security in U.S.A economy. The study builds a vintage growth, overlapping generations model in which individuals choose the length of education and the age of retirement. The study finds that social security pensions depend on workers past contributions, and social security has a positive effect on education, but pension benefits favor reductions in 
retirement age. The net effect is that starting from a benchmark case, higher life expectancies give rise to lower per capita GDP growth in the presence of social security as the share of the active population is reduced. In addition, higher social security contribution rates reduce the growth rate of per capita GDP.

Sianesi and Reenen, (2003) appointed the impact of human capital on macroeconomic performance on United Kingdom (UK) policy, the evidence claims that human capital increases productivity through education that affects long run growth rate of GDP. A one-year increase in average education raise the output per capita between 3 to 6 percent. Different levels of education depend on the level of country development. The type, the quality and the efficiency of education are matter for growth.

Lucas (1988), enters human capital in the production function as labor-augmenting form. The model provided human capital approach to endogenous growth. The main feature of the model is that human capital accumulation raises the productivity of both labor and physical capital. the engine of growth is human capital. The basic idea of the model is that people divide their time between work and training. So, there is a trade-off, since when taking on training people give up part of their work income, but raise their future productivity, and therefore their future wages. this trade-off is like the typical one appearing in physical capital accumulation. Thus, the decisions concerning the accumulation of human depend on the dynamic features of the economy, this model has two types of capital, physical and human capital. The fundamental equation of the model states that in steady-state the marginal product of the two types of capital must be the same. This implies that the dynamics of accumulation of the two types of capital are interlinked. consumer's welfare is given by an intertemporal constant-elasticity of substitution utility function. The 'effectiveness' of training, that is, the rate at which productivity is risen by one additional unit of training is exogenous. The main results are:

- The higher the productivity of training, the higher will be the increase in the marginal product labor that follows training and hence the higher the future wage rate. This means that the incentives to training are greater and so will be the growth rate of the economy.

- The lower is the rate of 'impatience', that is the less consumers privilege present relative to future consumption, the more will workers be willing to forsake present consumption to dedicate themselves to training. Therefore, the higher will be the rate of economic growth.

Barro (1996) empirical findings for a panel of 100 countries during the period (1960-1990) support that the growth rate is enhanced by higher initial schooling, life expectancy, fertility, government consumption, rules of law, inflation and terms of trade. In addition, Barro (1991), shows that the growth rate per capita GDP for 98 countries during the period (1960-1985) is positively to human capital and negatively related to the initial level of real per capita GDP.

\section{Data and Methodology}

\section{Data}

As I mentioned before the study will focus in education and economic growth in Jordan during the period from 1960-2015, the data will be annually and the data will be collected from International Monetary fund (IMF), The Word Bank (WB), UNESCO and the central bank of Jordan (CBJ). The main variables the study will covers are:

1. Gross Domestic Product (GDP) per capita as a proxy of economic Development.

2. Gross Enrollment Ratio (GER): this ratio can be calculated by taking the sum of primary, secondary and tertiary enrollment divided by population, and this ration is a proxy of human capital and education indicators. Following (Killer, 2006), Education affecting economic growth favorably in many ways as 
increasing productivity, literacy, the average level of education in the community, learning-how-to-learn, facilitating and creating the adoption of new technology and knowledge and lowering income inequality.

3. Education Expenditures as percentage of GDP (EDX), regarding (Awaworyi et al, 2017) education, relative to health, is a more important sector in promoting growth. Therefore, to promote growth, education relative to health may be a key sector to which public expenditure should be directed in the context of tight government budget constraints or budget deficits. The positive growth effect may imply that the positive effect of government human capital expenditure on economic growth may be largely through its impact on improved education and the positive spill-over effects that public schools generate.

4. Literacy rate (LR), as (National Adult literacy Agency, 2011) recommended good family literacy programs improve parent's ability to support their children's cognitive and non-cognitive development, leading to long term educational benefits. Such initiatives support the development of the human, social and cultural capital parents need to better support their children, while also providing parents with motivation to engage in learning. Adult literacy serves as a key component of adult learning systems and as a central mechanism for helping national governments to achieve their educational and economic goals. These goals are increasingly linked to the need for more highly skilled workforces. Education and training are crucial to economic and social change. The flexibility and security needed to achieve more and better jobs depend on ensuring that all citizens acquire key competences and update their skills throughout their live.

5. Life Expectancy (LE), (Ngangue et al, 2015) argued that life expectancy and health play a key role in economic growth in a country, and allowing the accumulation of knowledge and skill. People in good health live longer and are much more likely to invest in education. They are therefore more productive and contribute to the national income, job creation. Conversely, people in poor health have a low ability to learn and adapt to technological innovations within and therefore are less productive

6. Fertility ratio (FR), Pradhan, (2015) noticed that there is a negative correlation between different levels of female education and the total fertility rate (TFR), the economic theory of fertility suggests an incentive effect of this correlation, more educated women have higher opportunity costs of bearing children in terms of lost income. The household bargaining model suggests that more educated women are better able to support themselves and have more bargaining power, including on family size. According to the ideation theory, more educated women may learn different ideas of desired family size through school, community, and exposure to global communication networks. Finally, more educated women know more about prenatal care and child health, and hence might have lower fertility because of greater confidence that their children will survive. Female education has a greater impact on age of marriage and delayed fertility than male education. Although fertility falls when both male and female levels of education rise together, achieving gender parity in educational attainment could thus have a substantial effect on fertility rates.

7. Inflation(IN), and it will be measured by using the index of consumer price index in Jordan during the period 1960-2016.

8. Openness Ratio (OR), this index will be calculated by using sum of exports and imports to the gross domestic product.

\section{Methodology}

The study will focus on the Vector Auto Correction Model (VECM) to analysis the long-run relation of variables of interest. But before estimating the VECM, it is necessary to do some elementary important tests such as: 


\section{Unit Root Test}

To determine whether the variables of the study are unit root or stationary, for this purpose, the study conducted Augmented DickeyFuller test (ADF) and Philip Peron (PP) test and the results show that the variables are unit root at the level for both tests as shown in table 1 below, elsewise, the variables are stationary in the $1^{\text {st }}$ difference at $5 \%$ significance.

Table 1: unit root test results (Level)

\begin{tabular}{|c|c|c|c|c|}
\hline \multirow{2}{*}{ Variables } & \multicolumn{3}{|c|}{ Augmented DickeyFuller test Statistics } & \multicolumn{2}{c|}{ Philips Perron test statistics } \\
\cline { 2 - 5 } & intercept & Intercept \& trend & intercept & Intercept \& Trend \\
\hline GDP Per Capita & -1.510692 & -2.971966 & -1.307108 & -1.804122 \\
& $(0.5206)$ & $(0.1495)$ & $(0.6203)$ & $(0.6895)$ \\
\hline GER & -0.596239 & -2.015643 & -0.624478 & -2.093482 \\
& $(0.8628)$ & $(0.5801)$ & $(0.8564)$ & $(0.5380)$ \\
\hline EDX & -2.465707 & -2.967182 & -2.346594 & -2.974145 \\
& $(0.1292)$ & $(0.1505)$ & $(0.1615)$ & $(0.1486)$ \\
\hline LR & 0.880613 & 1.059342 & 1.405390 & 0.114656 \\
& $(0.9944)$ & $(0.9999)$ & $(0.9988)$ & $(0.9967)$ \\
\hline LE & -1.721112 & -0.196853 & -20.59543 & -6.091798 \\
& $(0.4151)$ & $(0.9916)$ & $(0.0211)$ & $(0.0011)$ \\
\hline FR & -3.148365 & -0.276284 & -2.849041 & 0.765917 \\
& $(0.0287)$ & $(0.9895)$ & $(0.0580)$ & $(0.9996)$ \\
\hline IN & -3.589234 & -3.571130 & -7.253452 & -7.205150 \\
& $(0.0091)$ & $(0.0418)$ & $(0.0468)$ & $(0.0352)$ \\
\hline OP & -2.967313 & -3.012356 & -2.775208 & -2.851920 \\
& $(0.0444)$ & $(0.1383)$ & $(0.0083)$ & $(0.1858)$ \\
\hline
\end{tabular}

\section{Cointegration Test}

Time series data can produce econometric problem due to spurious regression especially macroeconomic variables. So, when variables are non-stationary then errors are stochastic trend and this will produce also non- stationary process, and this means that there is a linking relationship between variables then cointegration becomes a powerful way to detect the non-stationary time series data. The key point to genuine long run between variables to exist or what is called integrative relationship. The cointegration test can be applied through using Johansen Cointegration test. The results of the test show that there is a long run relationship between variables of the study in I(2) as shown in table 2 below.

Table 2: Johansen Cointegration Test Results

\begin{tabular}{|c|c|c|c|c|}
\hline \multicolumn{5}{|c|}{$\begin{array}{l}\text { Sample (adjusted): } 19622016 \\
\text { Included observations: } 55 \text { after adjustments } \\
\text { Trend assumption: Linear deterministic trend } \\
\text { Series: GDP EDX FR GER IN LE LR OP } \\
\text { Lags interval (in first differences): } 1 \text { to } 1 \\
\text { Unrestricted Cointegration Rank Test (Trace) }\end{array}$} \\
\hline $\begin{array}{l}\text { Hypothesized } \\
\text { No. of } C E(s)\end{array}$ & Eigenvalue & $\begin{array}{c}\text { Trace } \\
\text { Statistic }\end{array}$ & $\begin{array}{c}0.05 \\
\text { Critical Value }\end{array}$ & Prob.** \\
\hline None * & 0.675172 & 189.4188 & 159.5297 & 0.0004 \\
\hline At most $1 *$ & 0.474158 & 127.5735 & 125.6154 & 0.0378 \\
\hline At most 2 & 0.408039 & 92.22207 & 95.75366 & 0.0854 \\
\hline At most 3 & 0.343851 & 63.38481 & 69.81889 & 0.1464 \\
\hline
\end{tabular}




\begin{tabular}{|c|c|c|c|c|}
\hline At most 4 & 0.281203 & 40.20959 & 47.85613 & 0.2151 \\
\hline At most 5 & 0.172125 & 22.04989 & 29.79707 & 0.2958 \\
\hline At most 6 & 0.165425 & 11.66075 & 15.49471 & 0.1739 \\
\hline At most 7 & 0.030699 & 1.714923 & 3.841466 & 0.1903 \\
\hline $\begin{array}{l}\text { Trace test indica } \\
* \text { denotes reject } \\
* * \text { MacKinnon-H }\end{array}$ & $\begin{array}{l}2 \text { cointegra } \\
\text { of the hypot } \\
\text { g-Michelis }\end{array}$ & $\begin{array}{l}\text { qn(s) at the }( \\
\text { at the } 0.051 \\
\text { p-values }\end{array}$ & level & \\
\hline Unrestricted Coi & gration Ranl & (Maximum & envalue) & \\
\hline $\begin{array}{l}\text { Hypothesized } \\
\text { No. of CE(s) }\end{array}$ & Eigenvalue & $\begin{array}{c}\text { Max-Eigen } \\
\text { Statistic }\end{array}$ & $\begin{array}{c}0.05 \\
\text { Critical Value }\end{array}$ & Prob.** \\
\hline None $*$ & 0.675172 & 61.84529 & 52.36261 & 0.0041 \\
\hline At most 1 & 0.474158 & 35.35146 & 46.23142 & 0.4377 \\
\hline At most 2 & 0.408039 & 28.83726 & 40.07757 & 0.5027 \\
\hline At most 3 & 0.343851 & 23.17522 & 33.87687 & 0.5171 \\
\hline At most 4 & 0.281203 & 18.15970 & 27.58434 & 0.4819 \\
\hline At most 5 & 0.172125 & 10.38914 & 21.13162 & 0.7075 \\
\hline At most 6 & 0.165425 & 9.945825 & 14.26460 & 0.2155 \\
\hline At most 7 & 0.030699 & 1.714923 & 3.841466 & 0.1903 \\
\hline $\begin{array}{l}\text { Max-eigenvalue } \\
* \text { denotes reject } \\
* * \text { MacKinnon-H }\end{array}$ & $\begin{array}{l}\text { tindicates } \\
\text { of the hypo } \\
\text { g-Michelis }\end{array}$ & $\begin{array}{l}\text { egrating eq } \\
\text { at the } 0.051 \\
\text { p-values }\end{array}$ & at the 0.05 level & \\
\hline
\end{tabular}

\section{Error Correction Model}

Since the variables are cointegrated, then the ECM can be expressed as:

$$
\Delta Y t=\alpha_{0}+b_{1} \Delta \mathrm{Xt}-\pi \hat{u_{t-1}}+Y t
$$

ECM is convenient model measuring the correction from disequilibrium of the previous period, and resolve the problem of spurious regression.

\section{The Results}

The results of ECM estimation in the long run shows that:

1. There is a negative relationship between economic growth and gross enrollment rate (GER) in Jordan during the period study, and this coefficient is statistically significant. This relation can be explained due to economic problems that economy in Jordan faced, and one of them is the high rate of unemployment especially for the educated people in the country and this lead to un productive economy and lower growth rates. The result suggests that an increase in GER by $10 \%$ lead to a decrease in GDP growth by $0.09 \%$.

2. There is a positive relationship between economic growth and government expenditures on education (EDX), and this coefficient is statistically significant. An increase in EDX by $10 \%$ increases economic growth by $2.9 \%$.

3. There is a positive relationship between economic growth and literacy rate and this coefficient is statistically significant. 
4. There is a positive relationship between economic growth and life expectancy and this coefficient is statistically significant.

5. There is a negative relationship between economic growth and fertility ratio and this coefficient is statistically significant.

6. There is a positive relationship between economic growth and inflation but this coefficient is statistically insignificant.

7. There is a positive relationship between economic growth and openness ratio and this coefficient is statistically significant.

The results of ECM can be formed in Table 3 below.

Table 3 ECM estimation Results

\begin{tabular}{|c|c|c|c|}
\hline Variables & Coefficient & Standard Error & P- Value \\
\hline Gross Enrollment Rate GRE & -0.009354 & 0.00263 & 3.55516 \\
\hline Government Expenditures EDX & 0.293877 & 0.02284 & 12.8656 \\
\hline Literacy Rate (LR) & 0.085552 & 0.01095 & 7.81241 \\
\hline Life Expectancy (LE) & 4.398092 & 1.22488 & 3.59063 \\
\hline Fertility Ratio (FR) & -0.092336 & 0.01083 & 8.52744 \\
\hline Inflation (IN) & 0.007922 & 0.00502 & 1.57917 \\
\hline Openness Ration (OR) & 0.269730 & 0.12291 & 2.19460 \\
\hline C & 1.406201 & 0.20372 & 6.90256 \\
\hline$R^{2}$ & \multicolumn{3}{|l}{} \\
\hline
\end{tabular}

\section{References}

Barbara, Sianesi, and John, Van, Reenen, (2003), The returns of education: Macroeconomics, Journal of Economic Surveys, 17(2), 157-200.

Barro, Robert, J., (2013), education and economic growth, Analysis of Economics and Finance, 14(2), 303 328.

Blaug, M., (1975), the economics of education in English classical political economy: A re-examination, in skinner Wilson (eds.), "Essay on Adam Smith", Oxford: Clarendon Press, pp. 568-599.

Cruz, A., Echevarria and Amaia, Iza, (2006), life expectancy, human capital, social security and growth, Journal of Public Economics, 90, 2323-2349.

Danacica, D., Belascu, L., \& Llie, L., (2010). The interactive causality between higher education and economic growth in Romania. International Review of Business Research Paper. 4(6), 491-500.

Dickens, W., T., Sawhil, I., and Tebbs, J., (2006), The effect of investing in early education on economic growth, The Brookings Institution.

Eric, Hanushek and Ludger, Wobmann. (2007), The role of education quality in economic growth, World Bank Policy Research, WP 4122.

Gilead, T., (2012), education and the logic of economic progress. Journal of Philosophy of education 46(1), $113-131$.

Haug, A.A., (2002), Temporal aggregation and the power of cointegration tests: A Monte Carlo study. Oxford Bulletin of Economics and Statistics, 64(4), 399-412.

Katarina, Killer, (2006), Investment in Primary, Secondary, and Higher Education and the Effects on Economic Growth, Contemporary Economic Policy, DOI: 10.1093/cep/byj012.

Lin, T., (2006), Alternative measure for education variable in an empirical economic growth model: Is primary education less important? Economics Bulletin 15: 1-6.

Lucas, E., (1998), on the mechanics of economic development, Journal of Monetary Economics, 22, 3-42.

Lucas, E. (1988), on the mechanics of economic development, Journal of Monetary Economics, 22(1), 342. 
Mankiw, G., Romer, D. and Weil, D. (1992), A contribution to the empirics of economic growth, Quarterly Journal of Economics, 107(2), 407-437.

Muhammad, Afzal, Muhammad, Farooq, Hafiz, Ahmad, Ishrat, Begum and M, Abdul Quddus, (2010). Relationship Between School Education and Economic Growth in Pakistan, Pakistan Economic and Social Review, 48(1), 39-60.

National Adult Literacy Agency, (2011), A literature Review of International Adult Literacy Policies, London.

Nelson, R., \& Phelps, E. (1966), investments in human capital, technological diffusion and economic growth, American Economic Review, 56(12), 69-75.

Ngwen, Ngangue, and Kouty, Manfred, (2015), The impact of life expectancy on economic growth in developing countries, Asian Economic and Financial Review, 5, (4), 653-660.

Pesaran, M.H., Y. Shin and R.J. Smith, (2001), Bounds testing approaches to the analysis of level relationships. Journal of Applied Econometrics, 16(3), 289-326.

Robert, J. Barro, (1996), determinants of economic growth: a cross country empirical study, National Bureau of Economic Research (NBER), WP No, 5698.

Robert, J. Barro, (1991), economic growth in a cross section of countries, The Quarterly Journal of economics, 106(2), 407-443.

Romer, P. (1990), endogenous technological change, Journal of Political Economy, 98(5), 71-102.

Schlottmann, A., M., (2010). Higher education and Economic Development: The Necessary Foundation. University of Nevada, Las Vegas.

Sefa, Awaworyi, Churchill, Siew, Ling, Yew, Mehmet, Ugur, (2015), Effects of government education and health expenditures on economic growth: A Meta-analysis, The B.E Journal of Macroeconomics, 17, (2), 1-3.

Timothy, J. Batrik and George, A. Erickcek, (2007), Higher education, health care industry and metropolitan regional economic development: what can eds \& meds do for the economic fortunes of metro areas residents, Upjohn Institute, WP, No. 80-140.

Vincent, Carpentier, (2006), public expenditures on education and economic growth in the USA in the nineteenth and twentieth Century in comparative perspective, institute of education, University of London. 